\title{
The Changing Role of Business in Chinese Society
}

\author{
Bin $\mathrm{Yu}$ \\ Ningbo Dahongying University \\ Ningbo, China
}

\begin{abstract}
Recently, the transformation of enterprises in China has been emphasized by the development of Chinese society. Chinese enterprises must be aware of their role change, actively participate in the competition in the world, carry out active innovation under the impetus of pressure, power and ability, and improve their core competitiveness and global competitiveness. Therefore, under the context of Chinese society, government and regulation or public perspective are essential on promoting CSR concept.
\end{abstract}

\section{Keywords—changing role; view of CSR; Chinese society}

\section{INTRODUCTION}

The old image of Chinese products and brand were always linked to the poor quality and OEM items. Recently, the transformation of enterprises in China has been emphasized by the development of Chinese society. Many firms realized the gap with international enterprises and the shortage on strategic management model. Under the promotion of brands, government, media, NPO, academics and other stakeholders, corporate social responsibility has become a popular topic in management.

In 1990s, the most typical CSR event is the social audit of a factory from international brands. This conventional CSR model lead China entered the first stage of the development of CSR. The second stage began from twentieth century. The representative phenomenon is CSR awards emerged endlessly and it became the focus of media and scholars. Government began to emphasis on the concept of "responsibility" around 2008. Innovations and thousands of social responsibility report from different firms showed roaring waves on the third stage of exploration.

Although there still a long way to go, social responsibility become a kind of consensus value was accepted widely in Chinese society. Booming developed CSR also bring the challenges at the same time. There is no doubt that Chinese business will change and retransformation in the future.

\section{ECONOMIC VIEW OF CSR}

The Classical economic argued for CSR and Milton Friedman is one of the influential scholars on the shareholder model of CSR. The debates around CSR often linked to his positions and writings. He highlights in his classic published work that "the social responsibility of business is to increase its profits". Five arguments were summarized and supported his work. The first position is that the organization is a artificial person rather than a corporeal person. Therefore, they only take artificial responsibilities not the moral one. The second view is the most significant of his point. Management's primary responsibility is to protect and promote the interests of their principals, mainly stockholders. For stockholders, the interest is only about data and outcomes. It is the fundamental basis between agents and principals. In addition, he attributed the theory of Taxation Analogy. The main opinion is the organization pay the tax to the government. Government uses tax for meeting stakeholder's interests. Such as fundamental construction, free primary education, environment governance and so on. Moreover, from a selfish perspective, shareholders money or the money earned by shareholders should be only used on shareholders. They do not have the duty of taking care of stakeholders. Lastly, he suggested that free market or free capitalism is the basis of free society. Classical CSR school identified that enterprise earn profits for shareholders based on the concept of "economic man" (Hailong, 2010).

"Invisible-hand" raised by Adam Smith in The Wealth of Nations pointed free market will balance and promote the interests between suppliers and demand within the community finally. Therefore, from Friedman's perspective, CSR should focus on increase profits. Levitt agreed on this point of view. The essential success for business could not be interfered by unrelated social concerns which should be done by government (Carroll and Shabana, 2010).

In the reality, market is not fair and balance, especially on the international market. A US toy producer cannot afford high cost and decided strategically to outsource and corporate with a Chinese toy maker after laying off 100 US workers. The saving not only is from the decreased salary from $\$ 1500$ (US worker) per month to $\$ 75$ per month (Chinese worker), but also the maintenance, electricity, plant costs and payroll. From the classical CR perspective, they are success on controlling outcome and no big ethical issues. However, New York Times published the poor working conditions at the Chinese factory. Then the brand has to face the ethical issues (Hill, 2009). From the case, it seems the factory paid salary and insurance for the employees and also paid tax to the government. They do not care much about working environment in order to save money.

\section{SOCIO-ECONOMIC VIEW OF CSR}

Socio-economic raised their perspective against classical views. One assumption of Classical CSR's point of view is there existing a transparent and perfect market. It is abstract 
and ideal. In the realistic, market mechanism is imperfect and leads to inefficiencies. For example, firms may hide some unsafe or unsure ingredients in food. Consumers will never know the harms. Employees who working in the firm might also know the details due to this information always kept in top classified. Furthermore, enterprises are existing in a social. Sustainable have to concern by corporation. Otherwise, there is meaningless for them to develop. Moreover, corporation not only service for shareholders but also requires more than shareholders, protecting citizenship interests and improves social welfare (Lantos, 2001). Maybe business may not benefit from preventing and rectifying harms or injuries in short term. There exists a 'moral minimum' concept which presents as a minimum moral level for a company. Although the pursuit of some good is not necessarily for the company, it definitely could see as an affirmative action for the firm's constituencies in long term (Simon et al, 1983). Affirmative duties could embed in corporate culture and strategy. Remedy way could not be seen as the first priority. If anticipating, planning and initiating thinking could prevent it happened, it may cost less and more practical (Carroll and Buchholtz, 2009). The accidents may unpredictable on business circumstances, especially obstacles which could not be anticipated.

Zijin Mining Group company Ltd. is a legend on saving cost. They invented extract gold by using sodium cyanide solution. In 2007, the cost per gram of gold mining is only RMB 57.64, forty five percentage of the average cost. On the process of extracting, toxic sodium cyanide and metal containing pollute water will be produces and have to be treated. However, they were not built sewerage system in the factory area due to save environmental protection input. Continuous rainfall made the leakage accidents happen on 3rd July, 2010. One hundred cubic meters of polluted water drained into Ding River and cased a large number of dead fish. The man is charge from the company claimed that the pollution only effected fish not to the health of citizens. The data from the bureau of water quality monitoring revealed that it was not the fact. Under the pressure of public, the company has invested RMB830 million to reconstruct the safety and environmental protection system in the following three years. All rectification results have been affirmed by the Ministry of Environmental Protection. Chairman mentioned that although the cost increased, the reputation help them to gain more benefits and stock price increased (Zhimin and Kuan, 2013).

Simon takes a case of Kew Gardens as an example to further explain his idea. Indeed, these thirty eight people were not break the law. It does not mean it is a good community. Unconcerned appeared on these thirty eight people when other people need help Could been called "under social behavior" (Rachel et al. 2007). The same uncaring news happened in China and had been arousing wide discussion and attention. On 13th October 2011, 2year-old Yueyue (real name is Wang Yue) have been rolled by two cars in Guangfo Hardware Industry Park. During those seven minutes, eighteen passers were indifferent and 'blind'. Finally, a waste picker aunt came to help the little girl. It was too late. After ten days, Yue dead in the hospital.
China has a moral history long time ago. When this news reported, someone said Chinese society become the coldest. We only do moral through oral rather than act. These eighteen Chinese passed by at that moment and have the ability to give a hand when the little girl needs them. From the camera, it is clear that these people all saw her but no one took the right or immediately action. The moral awareness is less than a waste picker (Shichuan, 2011). In the period of Yue stayed in the hospital, some people donated for her. Her father saved this money and paid for a Leukemia patient and acute aplastic anemia patient. Fortunately, there still exist numerous enthusiastic people.

\section{VIRTUE MARKET VIEW OF CSR}

Virtue market may become practice under some driving force. Recently, CSR theories focused from ethics orientation to a performance orientation which may more easily accepted by the enterprises. The empirical research examined firm financial performance under the effects of CSR implementation. Many results (Jackson, 2004; Laszlo, 2003; Waddock 2002) proved that the link between responsibility (CSR) and profitability (CFP) and stated that long-term value could be achieved by CSR. Vogel (2005) agreed that 'new world of CSR' is 'doing good to do well'. However, there is a market for virtue only based on pursues CSR activities supported by stakeholders (Carroll and Shabana, 2010).

Virtue ethics is the research object of moral phenomenon, which includes not only the moral consciousness phenomenon (such as personal moral feeling, etc.), but also the phenomenon of moral activity (such as moral behavior, etc.) as well as the phenomenon of moral norms. Ethics moral phenomenon separated from human activities, discussed the moral nature, origin and development, the relation between moral levels with the material standard of living, figured the meaning of life, people's value and attitude towards life. Corporation has ability to educate shared value. Shared value prevents social harms which can create internal costs within firms.

In China, due to the close link between economy environment and government policies, it is necessary to review with government actions. The fourth plenary session of the 18th CPC central Committee stated a concept of build a society under the combination of the rule of law and the rule of virtue. Therefore, the public and reporters discussed on the virtue market on different public media. For example, it is mentioned by Xiaomei Dai (2001) that manage corporation by virtue is the moral content of advanced corporate culture construction. Management by virtue is to inherit and carry forward the traditional culture of the Chinese nation and the objective requirements of the era of market economy. It is the fundamental guarantee of creating a new generation of professional managers in China. This is just one example of article mentioned about the importance of virtue market. In addition, some similar opinion raised by Chinese scholars on how can we implement virtue idea in dairy management process. Ethical and moral values have to build into employees thought and lead to the right actions. The company leaders have the right strategy on how 
embedding values and sprit by creating a harmonious environment (Chunhong, 2002).

\section{CSR IN CORPORATE CULTURE AND STRATEGY}

One reason for practitioners do not pay much attention on CSR is there were few empirical tests of the relationship between CSR and firm performance (Aguilera et al. 2007). CEOs may aware that raising societal expectations could be part of their competitive success. However, it is hard for them to implement on their daily management process or they even do not know how to embed CSR into corporate strategy (McKinsey and Company, 2006). Therefore, the practical operation, decisions and strategies based on ethics cultures is worth to discuss. Within this field, some scholars stated different theories to build social responsibility into 'Act'. Galbreath (2009) demonstrated from six dimensions approach to link CSR with firm's strategy Ethical code should express through the mission which is the fundamental purpose of an enterprise. Analysis strategic issues of socialrelated problems, dynamics social markets, value for customer, specificity intangible resources could help the firm to gain competitive advantages.

Konosuke Matsushita was known worldwide as the "God of management" and he agreed that profits could not be the ultimate goal of the pursuit for a corporation. The fundamental purpose of an enterprise is to seek improving human life through its business operation (Yan and Dezhi, 2009). More and more companies begin to build culture and seen it as a vital importance. However, few will link social responsibility with corporate culture. In fact, this is a lack of ideals and knowledge. On one hand, enterprises give full consideration to the social responsibility when construct their core culture and taking over social responsibility pro-actively. Not only they will gain a good reputation as well as attract top talent, but also increase customer satisfaction and loyalty and to obtain economic returns. On the other hand, corporate social responsibility can strengthen the cohesion function of enterprise culture, enhance incentive and restraint ability. Pointing clearly on the direction of culture development will create their own strong culture and build a bigger, stronger, long-term brand (Qinglin, 2013).

High quality products, success marketing campaign and solid enterprise culture could be the secret of the long lasted prosperous business. The former two successes often come from the culture. The core content of the enterprise culture is the enterprise ethics. Qixing Pharmaceutical Co., Ltd. is a typical example. They grew from a small family operation factory to today's top 50 patent drug corporation in China. They adhere to the "De, Xin, Xin, He" as their spirit. It means morality, trust, innovation, harmony. Morality is their first word in the mission. Returned to the society and country and consider enterprises are the primary spirit. However, it is not just a slogan. The broad often organize some activities to reminder employees on "morality". For example, they invite old soldiers' couple to share their life style. This couple never chase for material comforts or trouble for the government about inconvenient affairs. The speech touched workers, especially for those young people. In addition, the CEO made himself an example as well. At the beginning of the 1980s, Chinese women soccer team faced a huge financial problem. If they cannot overcome it, they have to dismiss. However, none of the enterprise would like to sponsor the team. Because although corporation need to pay RMB150 thousand per year, the team cannot use the sponsor's name. Factory manager knew the information. He provided the financial support without doubt. Millions went to support the development of Chinese women soccer team. Qixin became the strong backing. From thousand small things, employees remember their mission. The percentage of donation rose from sixty to eighty percentages to a hundred percent. Besides, they set up a strict supervisor system to monitor. Managing factory through culture becomes the source of strong cohesion, creativity, adaptability and endurance. It appears a good corporate image to the society (Qixing Pharmaceutical website).

\section{CITIZENSHIP VIEW OF CSR}

The latest debates on CSR focused on Citizenship theory. Corporation citizenship theory personifies a corporation, applying the concept of citizenship to the enterprise. The enterprise is a part of the society. Establishing and developing cannot be separated from the society. Any corporation no matter provides products or services all make a contribution to society and take responsibility to society. Therefore, corporate culture should including social responsibility regardless of leaders or workers. They should have an awareness of contributing to community.

Corporate citizenship reflects a common trend of corporate governance. It is a kind of penetration in the commercial field, a new commercial culture and business civilization. The only purpose of chasing economic value and ignore the social value and environmental value cannot survive in the competition of new business environment. Company must be aware of doing business equal to do corporate citizenship. Corporate citizenship is not only the external legal and moral norms, but also soft and intangible competence ability on combine social responsibility with ability. In order to achieve a balance among social harmony, social friendship and economic vitality, the first task should do a commitment to social responsibility (Yin, 2010).

A good corporate citizen s are aim to be profitable which is fulfill self-economic responsibilities, obeying the law, could meet the ethical responsibilities and engage in corporate contribution which could be seen as philanthropy (Carroll, 1998). In reality, Matten et al. (2005) questioned corporate citizenship theory failed to pay attention on the real concept of citizenship. It should including more forms than theory claimed, such as certain conditions, certain criteria and certain obligations.

The Alibaba Group, set up in Hangzhou in 1999, officially announced that it has become the largest retail trading platform on 6th April, 2016. As one of the most famous Chinese enterprise, they also act as the leader in the field of corporation social responsibility. A CSR website built up and annual social responsibility report were published every year. The enterprise committed to become a truly creating social value firm. They believe that everyone 
has a social responsibility and has the ability to fulfill it in the convenient environment of network. They ensure that social responsibility is not a burden on the enterprise. The combination between social responsibility and each business model could be found. They are firmly under the belief that only in the way of corporate social responsibility originated within the business model, enterprise could achieve sustainable development (website of Alibaba CSR). From the issued social responsibility report of 2014-2015, not only they did say this, but also they do it. In the total page of seventy two, they discussed from the concept of social responsibility in the mission, culture and strategies to the management of business model, and to the business actions in symbiotic circle as well as sharing circle.

The compass showed the combination of the mission, framework and social responsibility ecosystem. This dynamic compass states the economic value, social value and environmental value from the perspective of customers, employees, shareholders, marketplaces, society, government and environment. There are some examples on the action of Alibaba group to implement social responsibilities in their activities. Taobao.com help the local police to detect sold counterfeit sports shoes online by using big data on December 2014. In the industrial park of Alibaba, they opened bake house, super-larger fitness center, book store, film hall and flower shop. These infrastructures create a harmonious life and leisure environment for Alibaba's employees. Integrity department have regulation on accepting gifts from customers. If the refusing will cause the embarrassing which is common condition in Chinese traditional context, the fresh gift donate to public welfare people and the physical gifts donate to disability people or sale internal. All the money will be collected for public purposes. Relying on the Ali could, Zhejiang government network integrated services resources from more than forty provincial departments, eleven cities and ninety districts. This network connected data directly and make the administrative examination and approval more easily and time saving. The group proposed green office notion through conducting paperless work, using recycled paper, installation, remote control light, posting energy efficiency label, taking tailwind commute, promoting remote conference system and so on. All above cases are workable on business management and they pay attention on the small details. The firm labeled them as a citizen in Chinese society and win "2014 China Top 100 Green company" rewarded by "Daonong Center for enterprise and Green companies magazine." (Social Responsbility Report of Alibaba in 20142015).

\section{CONCLUSION}

Social responsibilities are established on a voluntary basis and higher than the relevant legal requirements. The production and business activities of enterprises have a positive impact on the community as well as contribute to the sustainable development of human beings (Liubin, 2007). This essay listed a trend of CSR theory and the changing role of Chinese business role.
Corporation social responsibility has a short development history in China compare with western on concept and actions. The practical far away behind market expectation and requests of society, impede the growth and development of enterprises and combat the global market competition of the national industries. From the research report on corporate social responsibility of China 2014 (Qunhui et al., 2015), the index of top 300 Chinese enterprises was 34.4 points and in the initial stage overall. In seven years, index continued to grow but the growth rate has declined. In addition, almost eighty percent of total firms get the score less than sixty. Only twenty-three firms achieved five stars in the stage of outstanding. Moreover, top 100 state-owned enterprises focused on operation under the regulation and increase the value of state-owned assets. Top 100 private enterprises focused on shareholders rights and community relations. Both domestic funded enterprises perform weak on the supply chain management. By contrast, foreign companies are Multinational Corporation. They disclosure more information on community relations and supply chain management. Lastly, the index of responsibility management and practice continued grow. Social responsibility index is higher than the market responsibility and environmental responsibility. It illustrated that the social responsibility management has been paid more and more attention by the enterprises, and gradually integrated with the practice.

Zhen's (2006) survey illustrated Chinese firms treated CSR as a demanding forces from outside while western firms treated it as a driving forces from inside. CSR is more than public show of donations to some programmers or disaster. Therefore, under the context of Chinese society, government and regulation or public perspective are essential on promoting CSR concept. It may create a CSR definition with Chinese characteristic (Meng, 2015). It is grad to observe that some enterprises embed citizenship theory as their action plan. Nevertheless, most corporation still only concentrate on profits and outcomes. Under this circumstance, government guidance and press publicity will be highly importance. The perfection of theoretical system and the practice of social responsibility will take the leader role in the management campaign.

\section{REFERENCES}

[1] Bowen, H. R. 1953. Social responsibilities of the businessman. New York: Harper \& Row.

[2] Liubin, C. 2007. Theoretical and Empirical Research on corporate social responsibility in China. Shandong Social Sciences, 2007(11):10-13.

[3] Chang, W. Deng, Z. and Shawn, P. D. 2012. Research progress of Foreign Corporate Social Responsibility and its Enlightenment. East China Economic Management, 26(03): 151.

[4] Hailong, L. 2010. Three genres on Corporation social responsibility researches. China Nonprofit Review, 2010(02): 98.

[5] Carroll, A. B. and Shabana, K. M. 2010. The business Case for Corporate Social Responsibility: A review of Concepts, Research and Practice. International Journal of Management Reviews, 12 (1):85105.

[6] Hill, C. W. L. 2009. Ethics in International business. http://highered.mcgrawhill.com/sites/dl/free/0072873957/121268/ethi cs_in_international_business.pdf, 20th April. 
[7] Carroll, A.B. and Buchholtz, A. K. 2009. Business and Society: Ethics and Stakeholder Management, 7th ed. Mason, OH: SouthWestern Cengage Learning.

[8] Lantos, G. P. 2001. The boundaries of strategic corporate social responsibility. Journal of Consumer Marketing, 18(7): 595-630.

[9] Simon, J. G. Powers, C. W. and Gunnemann, J. P. 1983. the responsibilities of corporations and their owners, The Ethical Investor, Universities and Corporate Responsibility. Yal University Press, New Haven, Conn.

[10] Rachel, M. Mark, L. and Alan, C. 2007. The Kitty Genovese murder and the social psychology of helping: the parable of the 38 witnesses. American Psychologist. 62(6): 555-62.

[11] Shichuan, W. 2011. Yue Yue passed away, there is no cold in heaven. Sina Web site. 21st October, http://news.sina.com.cn/pl/2011-1021/103023340450.shtml.

[12] Zhimin, Z. and Kuan, H. 2013. 830 million RMB on reconstruction the system of safety and environmental protection in Zijin Mining. 4th July, http://stock.sohu.com/20130704/n380629212.shtml.

[13] Jackson, K. T. 2004. Building Reputational Capital: Strategies for Integrity and Fair Play that Improve the Bottom Line. Oxford: Oxford University Press.

[14] Laszlo, C. 2003. The Sustainable Company: How to create Lasting Value through Social and environmental performance. Washington: Island Press.

[15] Waddock, S. 2002. Leading Corporate Citizens: Vision, Values, Value-added. New York: McGraw-Hill.

[16] Vogel, D. 2005. Is there a market for virtue? The business case for corporate social responsibility. California Management Review, 47:19-45.

[17] Carroll, A. B. and Shabana, K. M. 2010, The Business Case for Corporate Social Responsibility: A Review of Concepts, Research and Practice. International Journal of Management Reviews, 12(1): 85-105.

[18] Xiaomei, D. 2001. To Manage the Enterprise by Rule of Virtue - the Basis of Corporate Culture Construction. Chinese and Foreign Corporate Culture, 2001(7) : 21-27.

[19] Chunhong, Z. 2002. Improve the Management level by virtue management. Business Research, 2002(24): 33-35.

[20] Aguilera, R. V., Rupp, D.E., Williams, C. A. and Ganapathi, J. 2007, Putting the $\mathrm{S}$ back in Corporate social responsibility: a multi-level theory of social change in organizations, Academy of Management Review, 32(3): 836-63.

[21] McKinsey and Company, 2006. The McKinsey Global Survey of Business Executives: Business and Society. McKinsey \& Company. New York: NY.

[22] Galbreath, J. 2009. Building corporate social responsibility into strategy. European Business Review, 21(2): 109-127.

[23] Yan, L. and Dezhi, L. 2009. Discussion on Corporation Social Responsibility. Management \& Technology of SME, 36: 107.

[24] Qinglin, D. 2013. The relationship between enterprise culture and social responsibility. Course Education Research, 12: 24.

[25] Qixing Pharmaceutical website. http://www.qixing.com.cn/cn/profile.aspx. viewed on 27th April.

[26] Yin, L. 2010. Theory on social responsibility and corporate citizenship. Review of Economic Research, 2010(41): 62-64.

[27] Carroll, A. B. 1998. The four faces of corporate citizenship. Business \& Society Review. 100-101(1): 1-7.

[28] Matten, D. Crane, A. and Moon, J. 2005. Can Corporations be Citizens? Corporate citizenship as a Metaphor for Business Participation in Society. Business Ethics Quarterly, 15(3): 429-453.

[29] Website of Alibaba CSR. Alibaba Group. http://csr.alibaba.com. Viewed on 2nd May.

[30] Social Responsbility Report of Alibaba in 2014-2015. Alibaba Group. http://csr.alibaba.com/Uploads/file/20160125/56a5b8096e79e.pdf. Viewed on 2nd May.

[31] Zhen, C. 2006. A Cross Cultural comparative study of social responsibility behavior between Chinese and western Enterprises.
University of International Business and Economics. Master Dissertation.

[32] Qunhui, H. Huanggang, P, Hongwu, Z. Cong, Z. et al. 2015. Research Report on Corporate social responsibility of China (2014). Social Research Academic Press (China). http://www.cssn.cn/zk/zk_zkbg/201511/t20151102_2554823.shtml. Viewed on 2nd May.

[33] Meng, L. 2015. Is corporate social responsibility China's secret weapon? World Economic Forum. http://www.ecobusiness.com/opinion/corporate-social-responsibility-chinas-secretweapon/. Viewed on 2nd May. 